\title{
Malaría á Íslandi, sjaldgæf en stöðug ógn fyrir ferðalanga
}

\author{
Kristján Godsk Rögnvaldsson¹, Sigurður Guðmundsson¹,2, Magnús Gottfreðsson¹,2
}

\section{ÁGRIP}

Inngangur: Malaría er sníkjudýrasýking og ein algengasta orsök ótímabærra dauð̌sfalla í próunarlöndum, einkum međal barna. Sjúkdómurinn greinist af og til á Íslandi í einstaklingum sem hafa dvalist á malaríusvæðum. Í rannsókn sem gerð var á sjúkdómnum hérlendis 1980-1997 fundust 15 staðfest tilfelli. Tilgangur pessarar afturskyggnu rannsóknar var að rannsaka faraldsfræði malaríu 1998-2014 á Íslandi.

Efniviður og aðferðir: Sjúkragögn peirra sem greindust með malaríu hér á landi samkvæmt blóðstroki eđa blóðdropa voru yfirfarin. Einnig var aflað gagna um sölu malaríulyfja og um utanlandsferðir Íslendinga á tímabilinu. Niðurstöður: Staðfestar malaríusýkingar reyndust vera 31. Í heild voru að meðaltali 1,8 tilfelli á ári, greiningartíðni um 0,6 tilfelli/100 púsund íbúa/ ári. Á tímabilinu 1980-1997 var greiningartíoni 0,3/100 púsund/ári. Ekki reyndist marktækur munur á tíðni milli tímabila $(\mathrm{p}=0,056)$. Plasmodium falciparum greindist i $71 \%$ tilfella, $P$. vivax í 16\%, P. ovale og $P$. malariae hvor um sig i $7 \%$. Einungis tveir sjúklingar (7\%) höfðu tekið fyrirbyggjandi lyf. Einn sjúklingur fékk sýkingarbakslag. Tveir lögðust inn á gjörgæslu en enginn lést. Algengasta lyfjameðferð var atóvakón með prógúaníl. Sala pess sem fyrirbyggjandi lyfs stóð í stað árin 2010-2014 en á sama tíma varð aukning í utanlandsferðum Íslendinga.

Ályktun: Á Íslandi hefur greiningum á malaríu fjölgað lítillega en á sama tímabili hefur tilfellum í nágrannaríkjunum fækkað. Fylgjast parf með tíðni sjúkdómsins og afdrifum sjúklinga á Íslandi næstu ár. Mikilvægt er að efla forvarnir meðal ferðamanna á malaríusvæðum, par með talið töku fyrirbyggjandi lyfja.
Allir höfundarnir eru læknar.

'Læknadeild Háskóla Íslands, ${ }^{2}$ Landspítala.

Fyrirspurnir: Magnús Gottfreðsson

magnusgo@landspitali.is

desember 2015 sampykkt til birtinga 4. maí 2016

Höfundar hafa tfyllt eyðublað um hagsmunatengsl.

\section{Inngangur}

Malaría er alvarlegur smitsjúkdómur sem tekur stóran toll af mannkyninu á hverju ári. Malaríusníkillinn berst í menn með biti moskítóflugna og er áætlaður fjöldi slíkra sýkinga talinn hafa náð hámarki á heimsvísu árið 2003 pegar 232 milljónir manna sýktust. Fjöldi látinna vegna sýkingarinnar náði hámarki ári síðar pegar 1,2 milljónir manna létust. ${ }^{1,2}$ Talið er að 78\% peirra sem láta lífið séu börn undir 5 ára aldri og $90 \%$ dauðsfalla eigi sér stað í Afríku. Frá árinu 2000 til 2013 hefur nýgengi malaríu í heiminum lækkað um 47\% og um $54 \%$ í Afríku. ${ }^{2}$

Malaría greinist hérlendis af og til í einstaklingum sem hafa dvalið á svæðum par sem sjúkdómurinn er landlægur. Ein rannsókn hefur verið framkvæmd á tíðni malaríusýkinga á Íslandi, tímabilið 1980-1997. Á pví árabili fengu 19 einstaklingar greininguna og af peim voru 15 með staðfesta sýkingu samkvæmt blóðstroki. $^{3}$

Malaríu hefur nánast verið útrýmt sem landlægum sjúkdómi í Evrópu. Árið 2000 er talið að 32.405 einstaklingar hafi sýkst í álfunni en sú tala var komin niður í 41 tilfelli árið 2013; smit áttu sér stað einungis í Grikklandi (sem hafði verið malaríulaust í 36 ár), Tadsjikistan og Tyrklandi. ${ }^{2}$ Sama er uppi á teningnum í Bandaríkjunum og Kanada, en par voru innlend smit aðeins talin vera fjögur árið 2012. ${ }^{4}$

Helstu vopn í baráttunni við sjúkdóminn eru aðgerðir gegn moskítóflugum sem bera malaríu, notkun flugnaneta, fyrirbyggjandi lyfjagjöf pegar við á og viðeigandi meðferð sýktra. Markviss meðferð er háð réttri greiningu. Alpjóðaheilbrigðisstofnunin hefur síðan 2010 mælst til pess að blóð allra sem grunur leikur á að kunni að vera með malaríu sé prófað fyrir sýkingunni. ${ }^{2}$ Greining hefur um áratuga skeið byggt á smásjárskoðun á blóðstroki og pykkum blóðdropa, en aðferðirnar krefjast lágmarks tækjabúnaðar og vel pjálfaðs starfsfólk. Mikill skortur hefur verið á aðgengi að pessum greiningaraðferðum víða og hefur reynst gríðarlega tímafrekt og dýrt að koma peim upp. Af pessum sökum hafa ný og einföld skyndipróf (rapid tests) sem byggja á greiningu mótefnavaka malaríu verið próuð og eru komin í almenna notkun víða um heim. Árið 2013 var búið að dreifa meira en 160 milljónum skyndiprófa á heimsvísu, par af 133 milljónum prófa til Afríkuríkja. ${ }^{2}$

Malaríusýkingum sem eiga uppruna sinn utan Evrópu en greinast í álfunni, pað er innfluttum tilfellum, hefur fækkað síðustu ár. ${ }^{5}$ Sem dæmi má nefna að árið 2000 voru slík tilfelli 15.528 en hafði fækkað í 5970 árið 2013. ${ }^{6}$ Fækkunin varð mest á árunum 2000 til 2008 en árlegur fjöldi hefur haldist nokkuð stöðugur síðan. ${ }^{6}$ Afleiðingar malaríu eru misalvarlegar eftir pví hvaða sníkill á í hlut en einnig er talið að nýlegt ónæmissvar gegn fyrri sýkingum geti dregið úr einkennum smitist maður á nýjan leik.? Í nýlegri rannsókn í Bretlandi var dánartíðni vegna innfluttrar malaríu 3\% pess hóps fólks sem ferðaðist til malaríusvæða sem ferðamenn en tífalt 


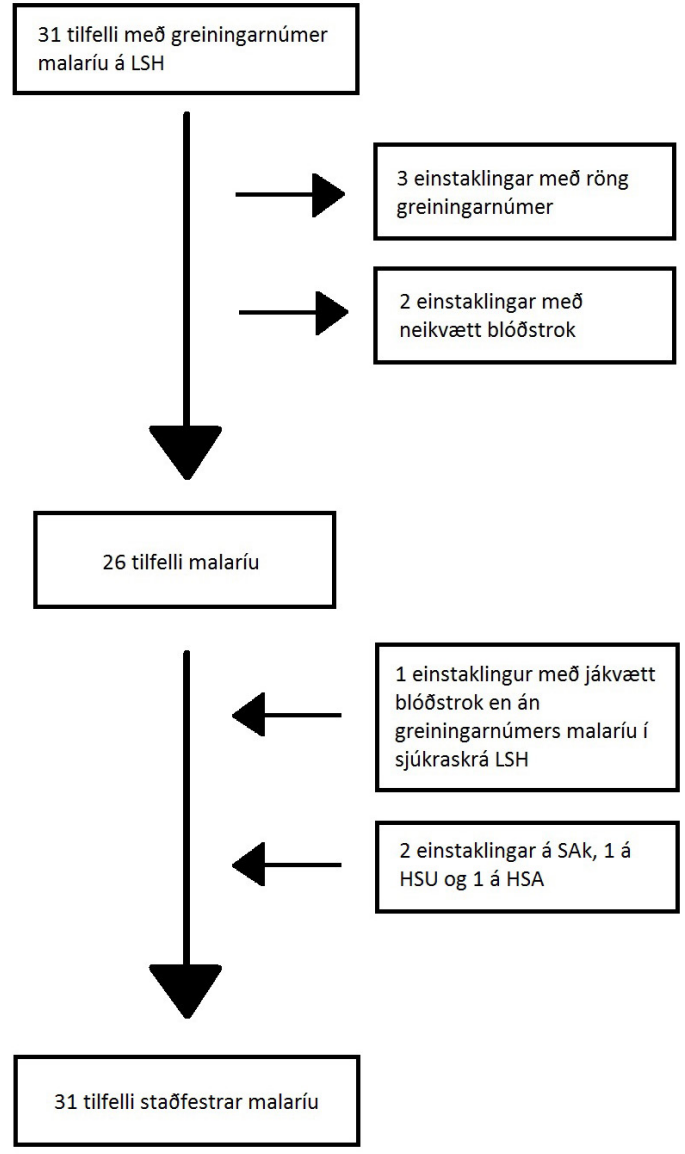

Mynd 1. Val rannsóknapýdis.

lægri, 0,32\%, meðal pess hóps sem hafði búið á malaríusvæðum áður og ferðaðist pangað aftur til að heimsækja ættingja og vini. Í sömu rannsókn sást að dánartíðni var $5 \%$ meðal peirra sem voru eldri en 65 ára, en um 0,5\% fyrir aldurshópinn 18-35 ára. Pá komu einnig fram vísbendingar um að dánartíðni væri hærri meðal peirra Breta sem greindust með malaríu eftir heimkomu og bjuggu í héruðum par sem fáir höfðu áður greinst með sjúkdóminn. ${ }^{8}$

Mikilvægt er fyrir íslenska lækna að hafa pessa greiningu í huga meðal veikra ferðalanga, einkum peirra sem nýlega hafa dvalist í Afríku eða Asíu. Prátt fyrir pað eru litlar sem engar upplýsingar til um faraldsfræði malaríu hér á landi, upprunaland smits eða afdrif peirra sem greinast. Með pessari rannsókn var markmiðið að bæta úr pví og gefa yfirlit yfir malaríutilfelli á Íslandi 1998-2014.

\section{Efniviður og aðferð̄ir}

\section{Val pýdis og leyfi}

Rannsóknin miðast við pau tilfelli sem greindust hér á landi árabilið 1998-2014. Jákvætt blóðstrok eða pykkur blóðdropi malaríu var sett sem skilyrði fyrir pví að tilfelli teldust gjaldgeng í úrtakshópinn. Öll sýni á Íslandi par sem grunur er um malaríu eru send á sýklafræðideild Landspítala til staðfestingar og tegundargreiningar. Eftir leit í gagnagrunni sýklafræðideildar fannst 31 jákvætt sýni fyrir malaríu. Sýnin komu frá Landspítala, Sjúkrahúsinu á Akureyri, Heilbrigðisstofnun Suðurlands og Heilbrigðisstofnun Austurlands. Einnig var leitað að ICD-greiningarnúmerum fyrir

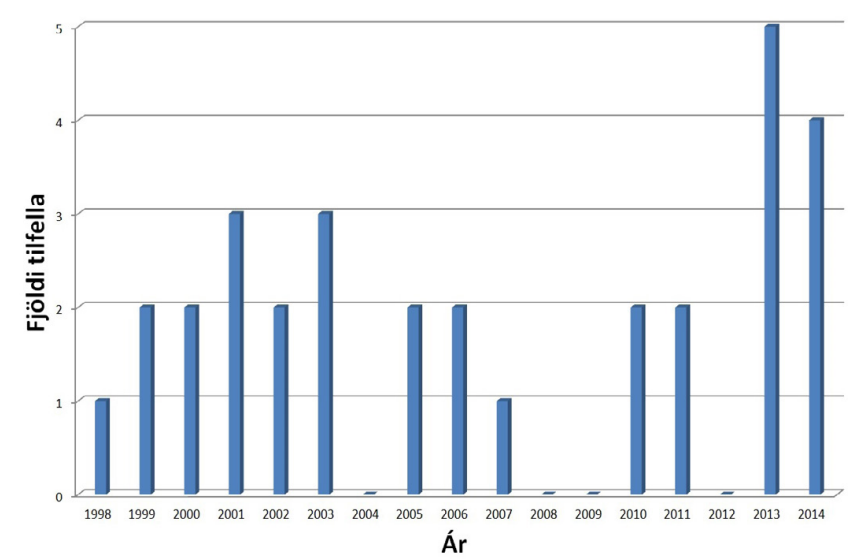

Mynd 2. Fjöldi staðfestra malaríusýkinga á Íslandi 1998-2014. Ekki greindist marktæk aukning tilfella innan tímabilsins.

malaríu (B50-B54) á Landspítala og komu pau fyrir í 31 tilviki en par af voru prír sem höfðu augljóslega fengið rangan kóða og tveir með neikvætt blóðstrok. Sjúkraskrá eins sjúklings sem var á pappír fannst ekki í skjalasöfnum Landspítala og pví fengust einungis takmarkaðar upplýsingar um pann aðila. Einn einstaklingur fékk malaríu í tvígang með eins árs millibili. Tvö tilfelli höfðu komið bæði á Landspítala og Sjúkrahúsið á Akureyri, pau voru ekki tvískráð. Staðfest tilfelli malaríu á tímabilinu 1998-2014, greind með jákvæðu blóðstroki, voru pví 31 en ítarleg gögn fundust um 30 tilfelli (mynd 1). Pegar mat var lagt á töku fyrirbyggjandi lyfja gegn malaríu var miðað við töku peirra innan við fjórum vikum fyrir upphaf einkenna, ella var talið að um enga slíka notkun hefði verið að ræða.

Til að bera saman hlutfallstölu peirra sem fengu malaríu á rannsóknatímabilinu við fyrra tímabil var fjöldi sýkinga á fjölda íbúa á Íslandi notaður til að reikna greiningartíðni. ${ }^{9}$ Ekki er hægt að kalla pessa stöðlun nýgengi par sem um innflutt smit er að ræða í öllum tilvikum og íbúahópurinn á Íslandi er ekki allur í hættu á að fá malaríu. Leyfi fyrir rannsókninni voru fengin hjá vísindasiðanefnd (VSN-15-031), og framkvæmdastjórum lækninga á Landspítala (Tilv. 16, LSH 25-15), Sjúkrahúsinu á Akureyri, Heilbrigðisstofnun Suðurlands og Heilbrigðisstofnun Austurlands.

\section{Ferðalög Íslendinga og heildsölutölur malaríulyfja}

Fengin voru gögn hjá Lyfjastofnun um heildsölutölur malaríulyfja og tölur frá Hagstofu Íslands um ferðalög Íslendinga um Leifsstöð. Einnig voru niðurstöður kannana sem birtust á síðu Ferðamálaráðs sem Markaðs- og miðlararannsóknir ehf. hafði framkvæmt nýttar við samanburð í rannsókninni. Helstu vandkvæði sem fylgja pví að skoða sölutölur lyfja sem notuð eru á fyrirbyggjandi hátt gegn malaríu eru meðal annars að pau hafa margar ólíkar ábendingar. Doxycýklín sem er tetracýklín-sýklalyf er mikið notað við ýmsum bakteríusýkingum, hýdroxyklórókín er notað í meðferð ýmissa gigtsjúkdóma. Atóvakón-prógúaníl og meflókvín hafa meðferð og fyrirbyggjandi meðferð malaríu sem ábendingu, en ekki aðra sjúkdóma. Pví gefur pað bestu nálgun á notkun fyrirbyggjandi lyfja við malaríu að nota sölutölur tveggja síðastnefndu lyfjanna. Atóvakón-prógúaníl kom á markað árið 


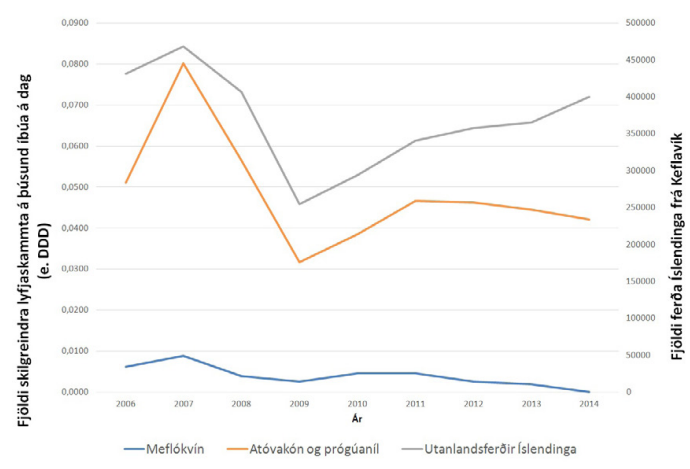

Mynd 3. Yfirlit um sölu fyrirbyggjandi malaríulyfja og ferðir Íslendinga um Leifsstöð. Á vinstri y-ás er fjöldi skilgreindra lyfjaskammta á púsund íbúa á dag af atóvakón-prógúaníl og meflókvíni. Á hægri y-ás er fjöldi Íslendinga sem ferðaðist í gegnum Keflavík á leið til útlanda. Dessi fyrirbyggjandi malaríulyf voru valin par sem pau hafa bæði einungis meðferð og fyrirbyggjandi meðferð malaríu sem ábendingar. Meflókvín var tekið af markaði í ágúst 2013.

2005 og meflókvín var tekið af markaði árið 2013. Pað veldur pví að tímabilið par sem hægt er að meta sölu lyfja til fyrirbyggjandi meðferðar malaríu er styttra en tímamörk pessarar rannsóknar. Par sem einungis eru að meðaltali 1,8 staðfest tilfelli malaríu á ári er langstærstur hluti seldra lyfja vegna fyrirbyggjandi notkunar.

\section{Tölfræðiúrvinnsla}

Notast var við forritið Microsoft Excel 2013 við skráningu gagna. Tölfræðileg greining var unnin í R (3.1.2) og Rstudio (0.98.1103). ${ }^{10,11}$ Gerð voru Fisher's exact próf, kí kvaðrat próf, línuleg og lógistísk aðhvarfsgreining eftir pví sem við átti. Notast var við tvíhliða próf með $\mathrm{p}<0,05$ til pess að ákveða hvort tölfræðilegri marktækni hafi verið náð.

Tafla I. Lýsing pýðis (\%).

\begin{tabular}{|c|c|}
\hline Meðalaldur & $32,6(31)^{\star}$ \\
\hline Fjöldi kvenna & 9 \\
\hline Fjöldi karla & 22 \\
\hline Fjöldi barna 10-18 ára & 4 \\
\hline Fjöldi barna $<10$ ára & 0 \\
\hline $\begin{array}{l}\text { Tími frá upphafi einkenna til } \\
\text { greiningar }\end{array}$ & 6,6 dagar $(5)^{\star}$ \\
\hline Algengustu einkenni & $\begin{array}{l}\text { Hiti (97), slappleiki (93), hrollur (59), uppköst } \\
\text { (45), beinverkir (45) og höfuðverkir (45) }\end{array}$ \\
\hline Heimshluti & Afríka sunnan Sahara (90) \\
\hline Dvalarland & $\begin{array}{l}\text { Gana í } 5 \text { tilfellum, Malaví, Nígería, Úganda og } \\
\text { flakk um mörg lönd hvert með prjú tilfelli. }\end{array}$ \\
\hline Ástæða dvalar erlendis & $\begin{array}{c}\text { Atvinna og búseta (48) } \\
\text { Heimsækja vini og ættingja (23) } \\
\text { Túristaferð (16) } \\
\text { Nýfluttir til Î́slands (7) } \\
\text { Ekki vitað (7) }\end{array}$ \\
\hline Fyrirbyggjandi lyf & $2 / 30(7)^{\star \star}$ \\
\hline
\end{tabular}

*miðgildi í sviga. **Einn hafði tekið lyfið atóvakón-prógúaníl stopult, annar einstaklingur hafði tekið fyrirbyggjandi malaríulyf en mundi ekki hvaða lyf.
Tafla II. Niðurstöður blóðrannsókna.

\begin{tabular}{|c|c|c|}
\hline Blóðrannsókn & Mælibil & Fjöldi tilfella (\%) \\
\hline \multirow[t]{5}{*}{ Lægstu blóðflögugildi } & $10 \pm 30 \times 10^{9} / \mathrm{L}$ & 7 \\
\hline & $30 \pm 100 \times 10^{9} / \mathrm{L}$ & 11 \\
\hline & $100 \pm 150 \times 10^{9} / \mathrm{L}$ & 6 \\
\hline & $>150 \times 10^{9} / \mathrm{L}$ & 6 \\
\hline & Ekki til mæling & 1 \\
\hline \multirow[t]{4}{*}{ Lægsta hemóglóbíngildi } & $70-100 \mathrm{~g} / \mathrm{L}$ & 6 \\
\hline & $100-134 \mathrm{~g} / \mathrm{L}$ & 15 \\
\hline & $>134 \mathrm{~g} / \mathrm{L}$ & 9 \\
\hline & Ekki til mæling & 1 \\
\hline \multirow[t]{4}{*}{ Sníkladreyri við komu } & $0-0,5 \%$ & 12 \\
\hline & $0,5-2 \%$ & 3 \\
\hline & $>2 \%$ & 9 \\
\hline & Ekki til talning & 7 \\
\hline Hæsta laktat- & $105-205 \mathrm{U} / \mathrm{L}$ & 1 \\
\hline \multirow{3}{*}{ dehýdrógenasagildi } & $205-300 \mathrm{U} / \mathrm{L}$ & 5 \\
\hline & $>300 \mathrm{U} / \mathrm{L}$ & 16 \\
\hline & Ekki til mæling & 9 \\
\hline \multirow[t]{4}{*}{ Hæsta kreatíníngildi } & 0-100 بmól/L & 22 \\
\hline & 100-150 بmól/L & 5 \\
\hline & >150 ㅆmól/L & 2 \\
\hline & Ekki til mæling & 2 \\
\hline \multirow[t]{4}{*}{ Hæsta bílírúbíngildi } & 5-25 ㅆmól/L & 11 \\
\hline & 25-50 umól/L & 4 \\
\hline & $>50$ بmól/L & 5 \\
\hline & Ekki til mæling & 11 \\
\hline \multirow[t]{5}{*}{ CRP-gildi við komu } & $0-10 \mathrm{mg} / \mathrm{L}$ & 0 \\
\hline & $10-50 \mathrm{mg} / \mathrm{L}$ & 6 \\
\hline & $50-100 \mathrm{mg} / \mathrm{L}$ & 10 \\
\hline & $>100$ mg/L & 9 \\
\hline & Ekki til mæling & 6 \\
\hline \multirow[t]{4}{*}{ Tegundargreining malaríu } & Plasmodium falciparum & $22(71)$ \\
\hline & P. vivax & $5(16)$ \\
\hline & P. ovale & $2(7)$ \\
\hline & P. malariae & $2(7)$ \\
\hline
\end{tabular}

$\mathrm{CRP}=$ C-reaktíft prótein

\section{Niðurstöður}

Greiningartíðni og faraldsfræði

Staðfestar malaríusýkingar á rannsóknatímabilinu voru 31 alls (mynd 2). Í heild greindust 1,8 tilfelli á ári að meðaltali, greiningartíðni reiknaðist pví um 0,6 tilfelli/100.000 íbúa/ári. Samkvæmt tölum úr fyrri rannsókn 1980-1997 og mannfjölda frá Hagstofu var reiknuð tíðni staðfestra sýkinga á pví tímabili 0,3/100.000 íbúa/ári, ${ }^{9}$ en munurinn á greiningartíðni reyndist ekki marktækur ( $\mathrm{p}=0,056$, Fisher's exact). Upplýsingar um sjúklingapýði rannsóknarinnar má finna í töflu I. Algengasti dvalarstaður fyrir smit var Gana. Flestir höfðu dvalist erlendis vegna atvinnu eða tímabundinnar búsetu. Tveir af hinum smituðu (7\%) kváðust hafa tekið malaríulyf í fyrirbyggjandi skyni, en upplýsingar um notkun fyrirbyggjandi lyfja voru takmarkaðar.

Niðurstöður blóðrannsókna

Samantekt á niðurstöðum helstu blóðrannsókna má finna í töflu II. Meirihluti sjúklinga hafði blóðflögugildi neðan viðmiðunarmarka og í aðeins einu tilviki reyndist laktat-dehýdrógenasa (LDH)-gildi vera eðlilegt. Við túlkun mæliniðurstaðna á hemóglóbíni, LDH 


\begin{tabular}{|c|c|}
\hline Lyf* & Fjöldi tilfella \\
\hline Atóvakón-prógúaníl & 15 \\
\hline Kínín & 8 \\
\hline Doxycýklín eða tetracýklín & 9 \\
\hline Melfkókvín & 6 \\
\hline Prímakvín & 5 \\
\hline Klórókín & 4 \\
\hline Artesúnat & 2 \\
\hline Klindamýcín & 1 \\
\hline Súlfadoxín-pýrímethamín & 1 \\
\hline Ekki til upplýsingar & 1 \\
\hline Lengd legu & 4,1 dagur að meðaltali, miðgildi 2 dagar \\
\hline Úrræði vegna alvarlegra veikinda & Fjöldi tilfella \\
\hline Fengu rauðblóðkornagjöf & 2 \\
\hline Fengu blóðflögugjöf & 3 \\
\hline Lega á gjörgæsludeild & 2 \\
\hline Blóđskilun vegna nýrnabilunar & 2 \\
\hline Öndunarvél & 1 \\
\hline Sýkingarbakslag & 1 \\
\hline Dauðsföll & 0 \\
\hline
\end{tabular}

*Notkun á fleira en einu malaríulyfi er algeng og pví er heildarfjöldi lyfja hærri en fjöldi tilfella

og kreatíníni verður að hafa í huga að viðmiðunarmörkin eru mismunandi fyrir ólíka hópa, einnig geta mörkin verið misjöfn milli ára og rannsóknarstofa. Ef frá er talin Plasmodium knowlesi greindust allar fjórar tegundir malaríu á Íslandi á tímabilinu, algengasta tegundin var Plasmodium falciparum. Marktækt línulegt samband var milli sníkladreyra (parasitemia) og hæsta CRP-gildis í legu, hæsta kreatíníns og lægsta hemóglóbíns ( $\mathrm{p}=0,005 ; \mathrm{p}=0,04$; $\mathrm{p}=0,04$ í sömu röð samkvæmt línulegri aðhvarfsgreiningu). Marktækt samband var milli lengdar sjúkralegu og lægsta blóðflögugildis ( $\mathrm{P}=0,02$, línuleg aðhvarfsgreining) og einnig milli lengdar sjúkralegu og sníkladreyra ( $\mathrm{p}=0,047$, línuleg aðhvarfsgreining).

\section{Afdrif og gangur ílegu}

Tafla III inniheldur samantekt á meðferð sjúklinga, lengd legu og afdrifum. Atóvakón-prógúaníl var oftast notað sem meðferð. Helmingurinn af einstaklingunum (15/30) var meðhöndlaður með tveimur eða fleiri lyfjum, pví er fjöldi lyfjameðferða meiri en fjöldi tilfella. Sjúklingar með P. falciparum sníkladreyra yfir $2 \%$ voru 9 talsins og par af voru fjórir einstaklingar hvorki meðhöndlaðir með artesúnati né kíníni. Einn sjúklingur fékk bakslag sýkingar. Enginn fékk malaríu með heilafylgikvillum (cerebral malaria) á tímabilinu en einn sjúklingur fékk brátt andnauðarheilkenni og purfti á öndunarvélarmeðferð að halda. Tveir fengu bráða nýrnabilun og purftu á blóðskilun að halda, kreatínín beggja fór yfir 800 $\mu$ mól/L. Enginn sjúklingur greindur með malaríu á rannsóknartímabilinu lést.

\section{Heildsölutölur malaríulyfja og ferðalög Íslendinga}

Eins og sjá má á mynd 3 fylgja sölutölur atóvakón-prógúaníl vel ferðalögum Íslendinga út fyrir landsteinana árin 2006-2010, en eftir pað virðist salan dragast saman, bæði á atóvakóni-prógúaníli og meflókvíni. Leitað var að gögnum um pað hvert Íslendingar væru að ferðast og hvort pað hefði breyst á rannsóknartímanum. Spurningakönnun MMR sem gerð var fyrir Ferðamálastofu árin 2012-2014 sýndi að hlutfall Íslendinga sem ferðuðust út fyrir Evrópu, Bandaríkin og Kanada var 6,2\% árið 2012, 5,5\% 2013 og 7,6\% árið 2014 (skekkjumörk 1,8-2\%). ${ }^{12-14}$ Einnig fundust gögn frá Hagstofunni sem sýndu að frá maí 2007 til apríl 2008 ferðuðust 3,8\% ferðamanna frá Íslandi til landa utan Evrópu, Bandaríkjanna og Kanada. ${ }^{15}$

\section{Umræður}

Faraldsfræði, blóðrannsóknir og afdrif

Í pessari rannsókn sýnum við fram á tilhneigingu til aukinnar greiningartíðni malaríu á Íslandi á sama tíma og greiningum sjúkdómsins fækkaði lítillega í nágrannaríkjunum. Malaríusýkingum fjölgaði miðað við tímabilið 1980-1997 að teknu tilliti til íbúafjölda. Innfluttum malaríutilfellum í Evrópu síðustu ár hefur fækkað lítillega. Greiningartíðni innfluttra malaríusýkinga í Evrópu í heild árið 2012 var 0,88 tilfelli/100.000 íbúa. ${ }^{5}$ Útreiknuð tíðni var 2,02/100.000 íbúa á ári í Danmörku á árunum 1998-2013 miðað við íbúafjöldatölur dönsku hagstofunnar fyrir hvert ár og 0,56/100.000 íbúa/ári á Íslandi sömu ár. ${ }^{6,16}$ Á tímabilinu 1994-2012 fækkaði hins vegar malaríugreiningum í Danmörku. ${ }^{17,18}$

Í rannsókninni sem gerð var hér á landi árin 1980-1997 höfðu flestir smitast í Afríku sunnan Sahara, eða 68\%, en í okkar rannsókn reyndust $90 \%$ sjúklinga hafa smitast par. Enginn lést vegna malaríu fremur en í fyrri rannsókninni. Flestir reyndust hafa $P$. falciparum á báðum tímabilum. ${ }^{3}$ Hlutfall $P$. falciparum sýkinga er hátt hér á landi og skýrist pað að einhverju leyti af pví að í 90\% tilvika má rekja smitið til Afríkuríkja par sem tíðni P. falciparum er hæst. ${ }^{2}$ Hlutfall malaríutilfella sem smitast í Afríku var 96\% í Danmörku árið 2014, ${ }^{18}$ par hafði sýkingum upprunnum í Asíu fækkað undanfarin ár en sýkingum frá Afríku ekki. ${ }^{17}$ Vitað er að $P$. falciparum sýkingar eru almennt alvarlegri en pær sem orsakast af $P$. vivax, $P$. ovale og $P$. malariae, ${ }^{19,20}$ pví má velta fyrir sér hvort vægar sýkingar með $P$. vivax og $P$. ovale kunni að vera vangreindar á Íslandi.

Niðurstöður úr blóðrannsóknum eru í samræmi við pað sem greint hefur verið frá í erlendum greinum enda er blóðflögufæð mjög algeng við malaríusýkingar. ${ }^{20-22}$ Nýrnabilun er einnig velpekktur fylgikvilli sjúkdómsins. ${ }^{23}$ Blóðflögur, rauð blóðkorn og hemóglóbín-gildi sýna neikvæða fylgni við magn sníkladreyra. ${ }^{24}$ Pví hefur verið lýst að CRP, LDH og bílírúbín hækki í malaríusýkingum. ${ }^{22,25}$ Lungnabjúgur og brátt andnauðarheilkenni er alvarlegur fylgikvilli sjúkdómsins með dánartíðni um $80 \%$ ef öndunarvél er ekki til staðar og rúmlega $50 \%$ prátt fyrir öndunarvélameðferð, ${ }^{20}$ voru pví að minnsta kosti tveir sjúklinganna í pessari rannsókn í bráðri lífshættu.

Einungis lítill hluti peirra sem greindist með malaríu hér á landi virðist hafa tekið fyrirbyggjandi lyf. Í nýlegri rannsókn kom í ljós að enginn í hópi finnskra sjúklinga með malaríu árin 20032011 hafði tekið fyrirbyggjandi lyf á réttan hátt. ${ }^{26}$ Í danskri rannsókn höfðu 65\% peirra sem fengu malaríu ekki tekið nein fyrirbyggjandi lyf. ${ }^{17}$ Pví virðist sem afar sjaldgæft sé að fá malaríu séu lyfin á annað borð tekin samkvæmt ráðleggingum. 
Í gögnum par sem sala atóvakón-prógúaníls og meflókvíns var skoðuð í samhengi við ferðalög Íslendinga til erlendra ríkja virðist sala peirra ekki fylgja auknum ferðalögum síðustu prjú til fjögur ár. Greina má aukningu á ferðalögum Íslendinga eftir efnahagshrun og svo virðist sem hlutfall ferðalaga út fyrir Evrópu, Kanada og Bandaríkin sé einnig að hækka. Við petta má bæta að síðustu tvö árin, 2013 og 2014, greindust tæp 30\% tilfellanna. Hvort kúfurinn síðustu tvö ár endurspegli tilviljun eða afleiðingar af minnkandi notkun á malaríulyfjum í fyrirbyggjandi tilgangi skal ósagt látið en pessi niðurstaða gefur tilefni til að skoða pað nánar. Í pví samhengi væri mögulegt að rannsaka betur ávísanir allra fyrirbyggjandi malaríulyfja á grunni greiningarkóða. Hins vegar skekkir pað lyfjasölutölurnar að ferðalangar kaupa fyrirbyggjandi lyf gegn malaríu erlendis í sumum tilvikum.

Takmarkanir pessarar rannsóknar eru svipaðar og almennt gildir um sjúkraskrárrannsóknir. Hafa verður í huga að skráningu getur stundum verið áfátt, til dæmis að pví er varðar einkenni, fyrirbyggjandi lyfjanotkun, ástæðu dvalar erlendis og tíma frá upphafi einkenna til greiningar. Pví parf að taka peim með ákveðnum fyrirvara. Á hinn bóginn er rannsóknin lýðgrunduð og tekur til allra staðfestra sýkinga. Afar ólíklegt er að við höfum misst af tilfellum sem greindust annars staðar á landinu, pó hugsanlegt sé að önnur tilvik af malaríu hafi verið meðhöndluð án staðfestrar greiningar. Fjöldi tilfella hér á landi er lágur og sveiflast mikið milli ára sem gerir ályktanir um breytingar á tíðni innan tímabils og milli tímabila erfiðar. Ekkert bendir pó til að sýkingunum fari fækkandi og pvert á móti má reikna með að ferðamönnum í áhættuhópi muni jafnvel fjölga í takt við aukin ferðalög, ekki síst ef töku lyfja í fyrirbyggjandi skyni er áfátt. Pví er mikilvægt að læknar hafi pessa sýkingu áfram í huga varðandi ferðalanga sem veikjast með hita, sér í lagi hafi leiðir peirra legið um Afríku.

\section{Pakkarord}

Sérstakar pakkir fá eftirfarandi aðilar fyrir veitta aðstoð: Karl G. Kristinsson, Hólmfríður Jensdóttir og Linda Helgadóttir á sýklafræðideild Landspítala, Ingibjörg Richter og Ubaldo Benitez Hernandez á Landspítala, Sigurður E. Sigurðsson og Snæbjörn Friðriksson hjá Sjúkrahúsinu á Akureyri, Pétur Heimisson hjá Heilbrigðisstofnun Austurlands, Hjörtur Kristjánsson á Heilbrigðisstofnun Suðurlands og Mímir Arnórsson hjá Lyfjastofnun.

\section{Heimildir}

1. Murray CI, Ortblad KF, Guinovart C, Lim SS, Wolock TM, Roberts DA, et al. Global, regional, and national incidence and mortality for HIV, tuberculosis, and malaria during 1990-2013: a systematic analysis for the Global Burden of Disease Study 2013. Lancet 2014; 384: 1005-70.

2. World Health Organization, World malaria report 2014, in World malaria report, W.H. Organization, Editor. World Health Organization, Genf 2014

3. Hjaltested EK, Hilmarsdóttir I, Guðmundsson S, Kristjánssson M. Malaríusýkingar á Íslandi árin 19801997, í: Rannsóknir í læknadeild Háskóla Íslands, IX. ráđstefna, 1999. Læknablaðið 1998; 84: 121.

4. Cullen KA, Arguin PM, Centers for Disease Control and Prevention (CDC). Malaria surveillance--United States, 2012. MMWR Surveill Summ 2014; 63: 1-22.

5. Albu C, Brusin S, Ciancio B. Annual epidemiologica report 2014 - Emerging and vector-borne diseases. 2014 European Centre for Disease Prevention and Control ecdc.europa.eu/. - nóvember 2015.

6. World Health Organization Regional Office for Europe Imported malaria cases. Centralized information system for infectious diseases (CISID). data.euro.who.int/cisid nóvember 2015.

7. Menard R, Tavares J, Cockburn I, Markus M, Zavala F, Amino R. Looking under the skin: the first steps in malarial infection and immunity. Nat Rev Microbiol 2013, 11: 701-12.
8. Checkley AM, Smith A, Smith V, Blaze M, Bradley D, Chiodini PL, et al. Risk factors for mortality from imported falciparum malaria in the United Kingdom ove 20 years: an observational study. BMJ 2012; 344: e2116.

9. Hagstofa Íslands. Lykiltölur mannfjöldans 1703-2015 2015, Hagstofa Íslands, Reykjavík 2015: hagstofan.is

10. Rstudio Team, RStudio: Integrated development environment for R 2015

11. R Development Core Team R. A language and environment for statistical computing. R Foundation for Statistical Computing. Vínarborg 2015.

12. MMR/Markaðs og miðlarannsóknir ehf. Ferðalög Íslendinga (ferðalög Íslendinga 2012 og ferðaáform peirra 2013). Ferðamálastofa, Reykjavík 2013.

13. MMR/Markaðs og miðlarannsóknir ehf, Ferðalög Íslendinga (ferðalög Íslendinga 2013 og ferðaáform peirra 2014). Ferðamálastofa, Reykjavík 2014.

14. MMR/Markaðs og miðlarannsóknir ehf, Ferðalög Íslendinga (ferðalög Íslendinga 2014 og ferðaáform peirra 2015). Ferðamálastofa, Reykjavík 2015.

15. Hagstofa Íslands. Ferðir erlendis eftir áfangastað 2007 2008. Hagstofa Íslands, Reykjavík 2008.

16. Danmarks Statistik, FOLK2: Folketal 1. januar efter køn alder, herkomst, oprindelsesland og statsborgerskab. Statistikbanken 2015: dst.dk

17. Moller $\mathrm{CH}$, David K. Imported malaria is stable from Africa but declining from Asia. Dan Med J 2014; 61: A4827.

18. Vestergaard LS, Nielsen HV. Malaria 2014, in EPI-NYT Statens serum institut, Kaupmannahöfn 2015.
19. Gorbach SL, Bartlett John G, Blacklow III, Bartlett NR. Infectious Diseases. 9 ed. Lippincott Williams \& Wilkins, Fíladelfíu 2004.

20. White NJ, Pukrittayakamee S, Hien TT, Faiz MA, Mokuol OA, Dondorp AM. Malaria. Lancet 2014; 383: 723-35.

21. Coelho HC, Lopes SC, Pimentel JP, Nogueira PA, Costa FT, Siqueira AM, et al. Thrombocytopenia in Plasmodium vivax malaria Is related to platelets phagocytosis. Plos One 2013; 8: e63410.

22. Gjorup IE, Vestergaard LS, Moller K, Ronn AM, Bygbjerg IC. Laboratory indicators of the diagnosis and course of imported malaria. Scand J Infect Dis 2007; 39: 707-13.

23. Shukla VS, Singh RG, Rathore SS, Usha. Outcome of malaria-associated acute kidney injury: a prospective study from a single center. Ren Fail 2013; 35: 801-5.

24. Kotepui M, Piwkham D, PhunPhuech B, Phiwklam N, Chupeerach C, Duangmano S. Effects of malaria parasite density on blood cell parameters. PLoS One 2015; 10: e0121057.

25. Kutsuna S, Hayakawa K, Kato Y, Fujiya Y, Mawatari M, Takeshita N, et al. The usefulness of serum C-reactive protein and total bilirubin levels for distinguishing between dengue fever and malaria in returned travelers. Am J Trop Med Hyg 2014; 90: 444-8.

26. Siikamäki H, Kivelä P, Lyytikäinen $\mathrm{O}$, Kantele A. Imported malaria in Finland 2003-2011: prospective nationwide data with rechecked background information Malar J 2013; 12: 93. 


\section{ENGLISH SUMMARY}

\section{Malaria in Iceland, a rare but looming threat for travelers}

Kristján Godsk Rögnvaldsson', Sigurður Guðmundsson ${ }^{1,2}$, Magnús Gottfreðsson ${ }^{1,2}$

Introduction: Malaria is one of the most common causes of preventable deaths in the developing countries, especially among children. A previous study of imported malaria in Iceland during 1980-1997 identified 15 confirmed cases. The objective of this retrospective study was to update epidemiological data on malaria in Iceland, 1998-2014.

Materials and methods: The inclusion criteria were a positive thick or thin blood smear for malaria parasites at the Dept. of Microbiology at Landspitali University Hospital, which serves as a referral laboratory for malaria diagnosis in the country. Medical records of confirmed cases, nationwide sales data for antimalarial agents and international travel of Icelanders were reviewed.

Results: Thirty-one cases of malaria were confirmed in Iceland during $1998-2014,1.8$ cases/year on average, a rate of 0.6 cases $/ 100.000$ inhabitants/year. The rate was $0.3 / 100.000$ inhabitants/year in the previ- ous study 1980-1997 ( $\mathrm{p}=0.056)$. Plasmodium falciparum was identified in $71 \%$ of cases, $P$. vivax in $16 \%, P$. ovale and $P$. malariae in $7 \%$ each. Only 2 patients $(7 \%)$ had used chemoprophylaxis prior to diagnosis. Two patients needed intensive care, but no fatalities were documented. One patient had a relapse. The most common agent used for treatment was atovaquone with proguanil, however annual sales figures plateaued during 2010-2014 despite a significant increase in foreign travel by Icelanders during the same period.

Conclusion: The detection rate for malaria in Iceland showed a tendency for increase between study periods while a slight decrease was noted in the neighbouring countries at the same time. The importance of antimalarial chemoprophylaxis and other preventive measures among Icelandic travellers to endemic areas needs to be emphasized.

'Faculty of Medicine, School of Health Sciences, University of Iceland, 'Landspitali University Hospital, Reykjavik, Iceland.

Key words: malaria, epidemiology, complications, treatment, travelers' health

Correspondence: Magnús Gottfreðsson, magnusgo@landspitali.is 